\section{Fruit Diameter and Daily Fruit Growth Rate of Three Apple Cultivars on Rootstock-Scion Combinations}

\author{
Ismail A. Hussein ${ }^{1}$ \\ Horticulture Section, Desert Research Center, Cairo, Egypt
}

Donald C. Slack ${ }^{2}$

Department of Agricultural Engineering, University of Arizona, Tucson, AZ 85721

Additional index words. apple, rootstock, fruit growth, arid lands

Abstract. The effect of three vigor-control apple (Malus domestics Borkh.) rootstock (seedling, MM.106, and M.7a) on fruit diameter of three cultivars ('Red Delicious', 'Granny Smith', and 'Gala') was studied over two growing seasons (1990-91) in the arid climate of Willcox, Ariz. Daily fruit growth rate (DFGR) and effective fruit growth period (EFGP) data indicate cultivar differences in DFGR as well as EFGP. Cultivars with a high DFGR had a relatively shorter EFGP. Rootstock had no significant effect on EFGP. Cultivar $x$ rootstock interaction on fruit diameter was significant for DFGR, but not for EFGP. 'Red Delicious' and 'Granny Smith' trees produced larger fruits on MM.106 and M.7a than on seedling rootstock. For 'Gala', there was no significant effect of all rootstock on fruit diameter.

Rootstock profoundly affected the performance of a given cultivar of apple (Lord et al., 1985). There can be $\geq 50 \%$ difference in yield of a given cultivar grown on different rootstock (Westwood, 1978). Rootstock also may have important effects on the performance of scion in apple, including precocity (Tubbs, 1973a), photosynthetic rate (Carr, 1966; Ferree and Barden, 1971), growth rate and duration (Roberts, 1949; Tubbs, 1973b), nutrient uptake (Chaplin and Westwood, 1980; Poling and Oberly, 1979; Schneider et al., 1978), budbreak (Brown et al., 1985; Stevens and Westwood, 1984; Young et al., 1979), and fruit size (Jackson and Blasco, 1975). Autio (1991 ) indicated that fruit size was dramatically affected by rootstock apart from the crop load. Preston et al. (1981) found that fruits from apple trees on M.7a were consistently larger than those from apple trees on M.27, M.26, or MM. 106. Similarly, Fallahi et al. (1 985) reported that 'Starkspur Golden Delicious' apple fruit on OAR1 were smaller than those from seedlings, MM. 106, M.7, or M.26. These findings suggest that growth of a given rootstock-scion combination is not necessarily indicative of performance of another scion cultivar on the same rootstock or of the same cultivar on another rootstock (Tubbs, 1973a). Therefore, the rootstock effect on fruit size is one of the important criteria for selecting the appropriate rootstock-scion combinations. Our objective

Received for publication 30 Apr. 1993. Accepted for publication 10 Aug. 1993. The cost of publishing this paper was defrayed in part by the payment of page charges. Under postal regulations, this paper therefore must be hereby marked advertisement solely to indicate this fact.

${ }^{1}$ Visiting Scientist.

${ }^{2}$ Professor and Head of Agricultural Engineering Dept. is to clarify the effect of rootstock-scion combination on fruit diameter of three apple cultivars grafted on three vigor-control rootstock.

To trace the response of rootstock-scion combination on fruit diameter, two criteria for judging seasonal variation in fruit growth diameter were used. The first criterion was daily fruit growth rate (DFGR), which expresses the regression of fruit diameter on fruit age (in days) from fruit set to fruit maturity; the second criterion was effective fruit growth period (EFGP), which defines that period of fruit growth during which the rate of growth is linear. EFGP was described by Daynard et al. (1 971) for maize (Zea mays L.) as the period during which most fruit growth takes place. Apple fruit development is defined by DFGR, duration of the EFGP, or both.

\section{Materials and Methods}

The study was performed in a commercial apple orchard in Willcox, Ariz., over the 199091 growing seasons. Willcox has an arid climate and is one of the biggest apple production areas in Arizona. The cultivars Red Delicious, without letters.
Granny Smith, and Gala were grafted on three size-controlling apple rootstock (seedling, MM. 106, and M.7a). 'Red Delicious' fruit is large and waxy and ripens from late September to mid-October. 'Gala' ('Golden Delicious' $x$ 'Cox's Orange Pippin' ) ripens during September. 'Granny Smith' is a large, waxy, grass-green fruit with an unusually long season; harvest is 170- 190 days after full bloom. The seedling rootstock is vigorous and produces a large tree. MM. 106 and M.7a are considered semidwarf rootstock. MM. 106 produces a tree $\approx 65 \%$ of standard size, and M.7a produces $55 \%$. to $65 \%$ of standard size (Rem and Carlson, 1987).

All trees were 7 years old and subjected to the ordinary horticultural practices for apple orchards. Flood irrigation was applied between borders located $75 \mathrm{~cm}$ on each side of the tree. Fruit was not thinned. Fruit diameter was measured on four trees for each cultivar representing replications. Five fruitlets were labeled at random, one fruitlet per cluster, on each of the 36 trees (three cultivars $\times$ three rootstocks $\times$ four replications). Fruit diameter measurements were made from mid-May up to mid-August in the two seasons. DFGR was calculated using the orthogonal polynomial model procedure of SAS (SAS Institute, 1987).

The EFGP was calculated with the following formula: $\mathrm{EFGP}=$ total increase in fruit diameter (in millimeters)/daily fruit growth (days) (Daynard et al., 1971).

All data were statistically analyzed according to a completely randomized design. Significance of differences among treatment means was judged using Duncan's multiple range test at $P \leq 0.05$.

\section{Results and Discussion}

Fruit diameter. 'Red Delicious' and 'Gala' had significantly larger diameters than 'Granny Smith' in both seasons (Table 1). 'Gala' and 'Red Delicious' had higher DFGRs and shorter EFGPs than 'Granny Smith', which had a relatively long EFGP but a low DFGR.

These data indicate that cultivar differences in fruit diameter reflect differences in DFGR as well as EFGP. A cultivar with high DFGR had a relatively shorter EFGP and vice versa. Furthermore, the data indicate that the DFGR might compensate for the shortness of the EFGP as observed in 'Red Delicious' and 'Gala'. Superiority in DFGR expresses the

Table 1. Mean fruit diameter, daily fruit growth rate (DFGR), and effective fruit growth period (EFGP) for three apple cultivars from mid-May to mid-Aug. 1990-91 in Willcox, Ariz.

\begin{tabular}{|c|c|c|c|c|c|c|}
\hline \multirow[b]{2}{*}{ Main effects } & \multicolumn{2}{|c|}{$\begin{array}{l}\text { Mean fruit diam } \\
(\mathrm{mm})\end{array}$} & \multicolumn{2}{|c|}{$\begin{array}{c}\text { DFGR } \\
(\mathrm{mm} / \text { day })\end{array}$} & \multicolumn{2}{|c|}{$\begin{array}{l}\text { EFGP } \\
\text { (days) }\end{array}$} \\
\hline & 1990 & 1991 & 1990 & 1991 & 1990 & 1991 \\
\hline \multicolumn{7}{|l|}{$\overline{\text { Cultivar effect }}$} \\
\hline Red Delicious & $67.7 \mathrm{a}$ & $68.4 \mathrm{a}$ & $0.45 \mathrm{a}$ & $0.50 \mathrm{a}$ & $89 \mathrm{~b}$ & $89 \mathrm{~b}$ \\
\hline Granny Smith & $63.0 \mathrm{c}$ & $63.3 \mathrm{c}$ & $0.38 \mathrm{~b}$ & $0.42 \mathrm{~b}$ & $94 a$ & $91 \mathrm{a}$ \\
\hline Gala & $64.9 \mathrm{~b}$ & 65.1 & $0.46 \mathrm{a}$ & $0.51 \mathrm{a}$ & $83 \mathrm{c}$ & $86 \mathrm{c}$ \\
\hline \multicolumn{7}{|l|}{ Rootstock effect } \\
\hline Seedling & $62.4 \mathrm{~b}$ & $63.0 \mathrm{~b}$ & $0.41 \mathrm{~b}$ & $0.44 \mathrm{~b}$ & 89 & 88 \\
\hline MM.106 & $66.2 \mathrm{a}$ & $66.5 \mathrm{a}$ & $0.43 \mathrm{ab}$ & $0.44 \mathrm{ab}$ & 88 & 88 \\
\hline M.7a & $67.0 \mathrm{a}$ & $67.4 \mathrm{a}$ & $0.45 \mathrm{a}$ & $0.52 \mathrm{a}$ & 89 & 89 \\
\hline
\end{tabular}

${ }^{2}$ Mean separation in columns by Duncan's multiple range test, $P \leq 05$. No significant differences in columns 
1990

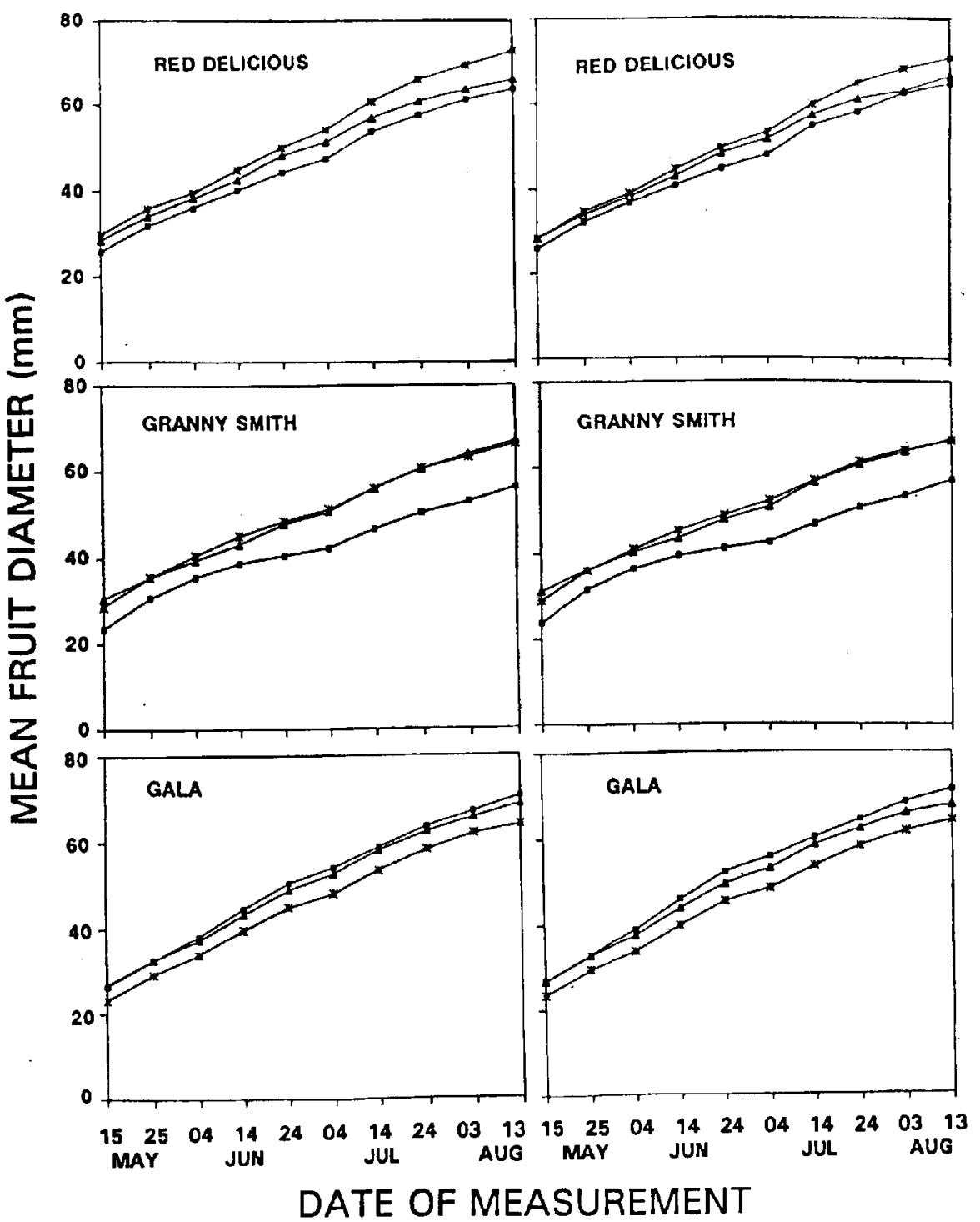

Fig. 1. Seasonal changes in fruit diameter of three apple cultivars as affected by rootstock $\times$ cultivar combinations. Seedling ( $\boldsymbol{\square})$, MM. 106 ( $\boldsymbol{\Delta}$ ), M.7a ( * ).

Table 2. Mean fruit diameter (MFD), daily fruit growth rate (DFGR), and effective fruit growth period (EFGP) for three apple cultivars as affected by cultivar $\times$ rootstock interaction from mid-May to midAug. 1990-91 in Willcox, Ariz.'

\begin{tabular}{|c|c|c|c|c|c|c|c|c|c|}
\hline \multirow[b]{2}{*}{ Rootstock } & \multicolumn{3}{|c|}{ Red Delicious } & \multicolumn{3}{|c|}{ Granny Smith } & \multicolumn{3}{|c|}{ Gala } \\
\hline & $\begin{array}{l}\text { MFD } \\
(\mathrm{mm})\end{array}$ & $\begin{array}{c}\text { DFGR } \\
\text { (mm/day) }\end{array}$ & $\begin{array}{r}\text { EFGP } \\
\text { (days) }\end{array}$ & $\begin{array}{l}\text { MFD } \\
(\mathrm{mm})\end{array}$ & $\begin{array}{r}\text { DFGR } \\
(\mathrm{mm} / \text { day })\end{array}$ & $\begin{array}{l}\text { EFGP } \\
\text { (days) }\end{array}$ & $\begin{array}{l}\text { MFD } \\
(\mathrm{mm})\end{array}$ & $\begin{array}{c}\text { DFGR } \\
\text { (mm/day) }\end{array}$ & $\begin{array}{l}\begin{array}{l}\text { EFGP } \\
\text { (days) }\end{array} \\
\end{array}$ \\
\hline \multicolumn{10}{|c|}{ First season } \\
\hline Seedling & 64.0 & b 0.43 & b 90 & $56.0 \mathrm{~b}$ & $0.33 b$ & $98 \mathrm{a}$ & 67.3 & 0.47 & 79 \\
\hline MM.106 & 66.1 & b 0.43 & b 88 & $66.9 \mathrm{a}$ & $0.41 \mathrm{a}$ & $90 \mathrm{~b}$ & 65.7 & 0.46 & 85 \\
\hline M.7a & 73.0 & a 0.49 & a 88 & $66.2 \mathrm{a}$ & $0.41 \mathrm{a}$ & $93 \mathrm{~b}$ & 61.8 & 0.45 & 86 \\
\hline \multicolumn{10}{|c|}{ Second season } \\
\hline Seedling & $65.0 \mathrm{~b}$ & $0.42 b$ & 89 & $56.4 \mathrm{~b}$ & 0.34 & b 92 & 68.0 & 0.47 & 87 \\
\hline MM.106 & $66.4 \mathrm{~b}$ & $0.43 b$ & 88 & $67.2 \mathrm{a}$ & $0.41 \quad \mathrm{a}$ & a 90 & 66.0 & 0.46 & 85 \\
\hline M.7a & $73.8 \mathrm{a}$ & $0.49 \mathrm{a}$ & 89 & $66.2 \mathrm{a}$ & $0.40 \quad \mathrm{a}$ & a 92 & 62.5 & 0.45 & 85 \\
\hline
\end{tabular}

'Mean separation in columns by Duncan's multiple range test, $P \leq 0.05$. No significant differences in columns without letters.

high rate of assimilate deposition and translocation in apple fruit.

Regarding the rootstock effect, seedling rootstock evidently produced smaller fruit than the two other rootstock (MM.106 and M.7a) in the two seasons. The latter produced fruit seasons. Our findings also indicate that the three rootstock' EFGPs were similar in the two seasons, despite the significant rootstock effect on DFGR during the two seasons.

These data agree with previous findings that indicate that rootstock can affect the scion in rate and duration of growth (Roberts, 1949; Tubbs, 1973 b).

Cultivar $\times$ rootstock. Regarding the effect of cultivar $\times$ rootstock interaction on fruit diameter, DFGR, and EFGP during the two growing seasons (Table 2 and Fig. 1), 'Red Delicious' and 'Granny Smith' produced larger fruit on both MM. 106 and M.7a rootstock than on the seedling rootstock. There was no significant interaction with 'Gala' on all rootstock, but there was a tendency to produce larger fruit on seedling or MM. 106 rootstock in the two seasons.

The data for cultivar $\times$ rootstock interaction reflect a higher DFGR on 'Red Delicious' $\times$ M.7a than for the other combinations with either MM. 106 or seedling rootstock in the two growing seasons. However, 'Granny Smith' grafted on MM. 106 or M.7a had a higher DFGR in the same order in the two seasons. Rootstock had no significant effect on DFGR in either season on 'Gala' rootstock. No significant differences could be detected in EFGP among all the treatments for the cultivar $x$ rootstock interaction.

This study shows that fruit diameter of a given cultivar differs depending on rootstockscion combinations. Differences in cultivar $x$ rootstock performance could be explained by cultivar differences in DFGR as well as EFGP. The data also indicate that the DFGR might compensate for the short EFGP of 'Red Delicious' and 'Gala'.

\section{Literature Cited}

Autio, R.W. 1991. Rootstock affect ripening and other qualities of Delicious apple. J. Amer. Sot. Hort, Sci. 116:378-382.

Brown, C. S., E. Young, and D.M. Pharr. 1985. Rootstock and scion in young apple trees. J. Amer. Soc. Hort, Sci. 110:696-701.

Carr, D.J. 1966, Metabolic and hormonal regulation of growth and development, p. 253-283. In: E.G. Gutter (ed,). Trends in plant morphogenesis. Longmans Green, London.

Chaplin, M.H. and M.N. Westwood. 1980. Nutritional status of 'Bartlett' pear on Cydonia and Pyrus species rootstock. J. Amer. Soc. Hort. Sci. 105:60-63.

Daynard, T. B., J.W. Tanner, and G.W Duncan. 1971. Duration of grain filling period and its relation to grain yield in corn (Zea mays L.). Crop Sci. 11:45-48.

Fallahi, E., D.G. Richardson, and M.N. Westwood. 1985. Quality of apple fruit from a high density orchard as influenced by rootstock, fertilizers, maturity, and storage. J. Amer. Soc. Hort. Sci. 110:71-74.

Ferree, M.E. and J.A. Barden. 1971. The influence of strains and rootstock on photosynthesis, respiration and morphology of 'Delicious' apple trees. J. Amer. Soc. Hort. Sci. 96:453457.

Jackson, J.E. and A.B. Blasco. 1975. Effects of rootstock and crop load on fruit size and quality of Cox's Orange Pippin and Worcester Pearmain, Rpt. E. Mailing Res. Sta. p. 45. 
Lord, W.J., D.W. Greene, R.A. Damon, Jr., and J.H Baker. 1985. Effects of stempiece and rootstock combinations on growth, leaf mineral concentrations, yield, and fruit quality of 'Empire' apple trees. J. Amer. Soc. Hort. Sci. 110:422425.

Poling, E.B. and G.H. Oberly. 1979, Effect of rootstock on mineral composition of apple leaves. J. Amer. Soc. Hort. Sci. 104:799-801.

Preston, A.P., D.E. Belcher, and B.C. Ley. 1981. Apple rootstock studies: Bramley's seedling on dwarfing clones. Expt. Hort. 32:18-24.

Roberts, L.W. 1949. Theoretical aspects of graft- age. Bet. Rev. 15:423-463.

Rem, R.C. and R.F. Carlson (eds.), 1987. Rootstock for fruit crop. Wiley, New York.

SAS Institute. 1978. SAS/Stat guide for persona computers. version 6 ed. SAS Institute, Inc., Cary, N.C.

Schneider, G. W., C.E. Chaplin, and D.C. Martin. 1978. Effects of apple rootstock, tree spacing, and cultivar on fruit and tree size, yield, and foliar mineral composition. J. Amer. Soc. Hort Sci. 103:230-232.

Stevens, G.A. and M.N. Westwood. 1984. Fruit set and cytokinin like activity in the xylem sap of sweet cherry (Prunus avium) as affected by rootstock. Physiol. Plant. 61:464-468.

Tubbs, F.R. 1973a. Research fields in the interaction of rootstock and scions in woody perennials. I. Hort. Abstr. 43:247-253.

Tubbs, F.R. 1973b. Research fields in the interaction of rootstock and scions in woody perennials. II. Hort. Abstr. 43:325-335.

Westwood, MN. 1978. Temperate zone pomology. W.H. Freeman, San Francisco.

Young, E, and B. Olcott-Reid. 1979. Siberian C rootstock delays bloom of peach. J. Amer. Soc. Host. Sci. 104:178-181. 